\title{
IMPLEMENTASI KELAS VIRTUAL DENGAN GOOGLE CLASSROOM UNTUK MENINGKATKAN HASIL BELAJAR KIMIA DI SMA NEGERI BEKASI Dwining Bintarawati', Yudin Citriadin ${ }^{2}$
}

SMAN 1 Serang Baru, Kabupaten Bekasi, Jawa Barat, 17330. email: dwining286@gmail.com

Universitas Islam Negeri Mataram, Kota Mataram, NTB 83125. email: yudin.citriadin@uinmataram.ac.id

\section{ABSTRAK}

Penelitian ini bertujuan untuk mengidentifikasi implementasi kelas virtual dengan Google Classroom dalam meningkatkan hasil belajar kimia. Metode penelitian yang digunakan dalam penelitian ini merupakan penelitian tindakan kelas yang dilaksanakan dalam 2 siklus. Setiap siklus terdiri atas 4 tahapan yaitu: perencanaan, pelaksanaan, pengamatan, dan refleksi. Subjek penelitian adalah seluruh siswa kelas XI-MIPA 1 SMAN 1 Serang Baru. Teknik pengumpulan data dilakukan melalui observasi aktivitas pembelajaran dan hasil tes siswa pada mata pelajaran kimia. Setelah semua data terkumpul, analisis data dengan menggunakan rumus persentase. Berdasarkan hasil penelitian diperoleh aktivitas siswa dalam impelemntasi kelas virtual dengan Google Classroom mengalami peningkatan dari siklus I dan siklus II dengan persentase 92,31\% menjadi 94,23\%. Sedangkan hasil belajar siswa mengalami peningkatan secara klasikal dari 70, 94\% pada siklus I menjadi $88,88 \%$ pada siklus II. Dari hasil penelitian dan analisis data dapat disimpulkan bahwa implementasi menggunakan kelas virtual dengan Google Classroom dapat meningkatkan aktivitas dan hasil belajar kimia di SMAN 1 Serang Baru. Kelas virtual melalui Google Classroom dapat dijadikan solusi dalam pembelajaran daring di tengah wabah pandemi Covid-19.

Kata kunci: Google Classroom, Kelas Virtual 


\section{PENDAHULUAN}

Seiring dengan wabah penyebaran virus Covid-19 di Indonesia, berdampak pada dunia pendidikan. Kegiatan belajar mengajar yang biasanya dilakukan dengan metode tatap muka di kelas, menjadi beralih ke kegiatan belajar mengajar di rumah melalui pembelajaran daring/jarak jauh. Berdasarkan Surat Edaran Menteri Pendidikan dan Kebudayaan Republik Indonesia Nomor 4 Tahun 2020 Tentang Pelaksanaan Kebijakan Pendidikan Dalam Masa Darurat Penyebaran Covid-19, menjelaskan bahwa pembelajaran daring/ jarak jauh dilaksanakan untuk memberikan pengalaman belajar yang bermakna bagi siswa. Belajar dari rumah difokuskan pada pendidikan kecakapan hidup antara lain mengenai pandemi Covid-19 (Kemdikbud, 2020).

Pembelajaran daring merupakan pemanfaatan jaringan internet dalam proses pembelajaran. Pembelajaran daring siswa memiliki keleluasaan waktu belajar, dapat belajar kapanpun dan dimanapun (Isman dalam Dewi, 2020). Interaksi antara guru dan siswa dalam pembelajaran daring dapat menggunakan beberapa aplikasi atau flatform gratis yang berupa kelas virtual, seperti Google Classroom, Edmodo, dan Schoology. Aplikasi Google Classroom dipilih peneliti dalam penelitian ini karena merupakan salah satu bentuk aplikasi learning management system (LMS) yang paling banyak digunakan oleh siswa karena mudah untuk digunakan dan siswa lebih familiar. Google Classroom dapat membantu guru membangun kelas virtual sesuai dengan kondisi pembelajaran di kelas, berdasarkan pembagian kelas nyata di sekolah, di mana kelas-kelas yang terkandung dalam tugas, kuis dan tugas pada akhir setiap pelajaran. Pembelajaran online, interaksi dan komunikasi di dalam kelas dapat dilaksanakan seperti di kelas konvensional dengan menggunakan media Google Classroom ini, di mana setiap siswa dapat dengan bebas berkomunikasi dan berbagi dengan guru dan teman sekelas, untuk menanggapi materi yang disampaikan. 
Ilmu kimia adalah ilmu yang mempelajari tentang komposisi, struktur, sifat, perubahan, dan energi yang menyertainya. Dalam kimia dipelajari tentang fenomena alam. Berdasarkan fenomenafenomena alam ini, disusun konsep-konsep, teori-teori, dan hukumhukum. Konsep-konsep, teori-teori, dan hukum-hukum ini kemudian dapat digunakan kembali untuk menjelaskan berbagai fenomena yang terjadi di alam. Dalam menjelaskan fenomena alam ini, kimia mengaitkan tiga level, yaitu makroskopik, mikroskopik, dan simbolik (Gabel dalam Redhana, 2019). Ilmu kimia bersifat abstrak dan memerlukan keaktifan siswa dalam memecahkan berbagai masalah dalam persoalan yang berhubungan dengan kimia baik dalam ruang lingkup sekolah maupun diluar ruang lingkup sekolah (sehari- hari). Kimia pada tingkat sekolah sudah mulai diajarkan pada tingkat sekolah menengah atas.

Pembelajaran kimia di sekolah pada masa pembelajaran jarak jauh dapat dilakukan dengan memanfaatkan kelas virtual menggunakan aplikasi Google Classroom. Google Classroom dapat menjadi sarana distribusi tugas, submit tugas bahkan menilai tugastugas yang dikumpulkan (Hammi, 2017). Aplikasi ini juga dapat membantu memudahkan guru dan siswa dalam melaksanakan proses belajar dengan lebih mendalam. Hal ini disebabkan karena baik siswa maupun guru dapat mengumpulkan tugas, mendistrubusikan tugas, menilai tugas di rumah atau dimanapun tanpa terikat batas waktu atau jam pelajaran.

Google Classroom dirancang unttuk mempermudah interaksi guru dan siswa dalam dunia maya. Aplikasi ini memberikan kesempatan kepada guru untuk mengekplorasi gagasan keilmuan yang dimilikinya kepada siswa (Hammi, 2017). Guru memiliki keleluasaan waktu untuk membagikan kajian keilmuan dan memberikan tugas mandiri kepada siswa. Selain itu, guru juga dapat membuka ruang diskusi bagi para siswa secara online.

Aplikasi Google Classroom ini dapat digunakan oleh siapa saja yang tergabung dengan kelas yang didesain oleh guru yang sesuai dengan kelas sesungguhnya atau kelas nyata di sekolah. Aplikasi ini juga dirancang untuk membantu guru menghemat waktu dalam hal 
membuat salinan google dokumen secara otomatis bagi setiap siswa ketika memberikan tugas. Google Classroom juga dapat membuat folder drive untuk setiap tugas siswa agar semuanya tetap teratur (Hammi, 2017).

Hasil penelitian yang dilakukan oleh Suhada, dkk pada tahun 2020, yang meneliti pembelajaran daring berbasis Google Classroom pada mahasiswa pendidikan biologi pada masa wabah Covid-19 menunjukkan bahwa penggunaan aplikasi Google Classroom dalam pembelajaran daring pada masa wabah Covid-19 sudah cukup baik dan efektif. Akan tetapi, akan lebih baik jika dalam pembelajaran dipadukan dengan platform online lainnya (Suhada, dkk., 2020).

Hasil penelitian terdahulu yang dilakukan oleh Hamzarudin, dkk., pada tahun 2020 menunjukkan bahwa Google Classroom layak digunakan sebagai media pembelajaran karena menunjukan ratarata validasi yang sangat baik. Pemanfaatan LMS berbasis Google Classroom yang diterapkan dalam pembelajaran sangat efektif, karena Google Classroom banyak mendapatkan respon positif dari siswa, mahasiswa, dan pengguna lainnya. Penggunaan Google Classroom ini memberi dampak yang baik terhadap hasil belajar dan mempermudah proses pembelajaran karena guru menghabiskan lebih banyak waktu dengan siswa dan lebih sedikit waktu untuk urusan administrasi (Hamzarudin, dkk., 2020).

Aplikasi Google Classroom ini diimplementasikan dalam pembelajaran kimia di SMAN 1 Serang Baru. SMAN 1 Serang Baru merupakan sekolah SMA negeri yang menerapkan kurikulum 2013 dalam pembelajaran. Dengan penggunaan Google Classroom ini pada pembelajaran kimia di SMAN 1 Serang Baru akan mencapai tujuan yang diharapkan dalam kurikulum 2013 ditengah wabah pandemi Covid-19 yang mengharuskan siswa belajar di rumah.

Implementasi kelas virtual menggunakan Google Classroom dalam pembelajaran kimia dapat meningkatkan hasil belajar kimia di SMA Negeri 1 Serang Baru dan dapat menjadi solusi pembelajaran kelas yang tidak dapat dilakukan secara tatap muka di tengah wabah pandemi Covid-19. 


\section{METODE PENELITIAN}

Penelitian ini menggunakan rancangan penelitian tindakan kelas (classroom action research) dimana pada penelitian tindakan dapat dipandang sebagai tindak lanjut dari penelitian deskriptif dan eksperimen. Penelitian tindakan bukan lagi mengetes sebuah perlakuan, tetapi sudah mempunyai keyakinan akan ampuhnya suatu perlakuan (Suhardjono, 2009). Adapun penelitian tindakan kelas ini mengacu pada model Kemmis dan Mc. Taggrat (Suharsimi, 2009). Penelitian tindakan kelas ini dilakukan dalam 2 siklus dengan masing-masing siklus terdiri dari tahap perencanaan, pelaksanaan tindakan, pengamatan (observasi) dan refleksi.

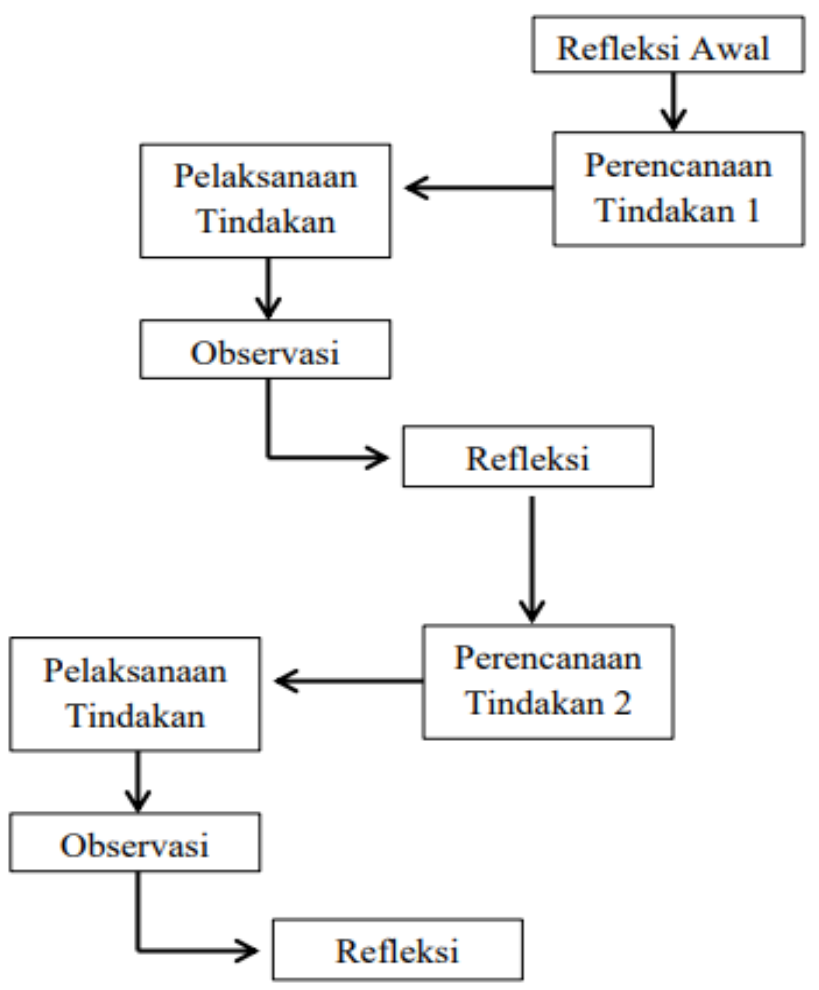

Gambar 1. Siklus PTK menurut Kemmis dan Mc Taggart 
Subyek penelitian adalah siswa kelas XI MIPA 1 SMA Negeri 1 Serang Baru. Teknik pengumpulan data pada penelitian ini menggunakan tiga instrumen penelitian yaitu, lembar observasi, angket, dan tes hasil belajar. Teknik analisis data yang dilakukan dalam penelitian tindakan kelas ini meliputi yaitu reduksi data (data reduction), penyajian data (data display), dan penarikan kesimpulan/verifikasi data (conclusion drawing/verification) (Sugiyono, 2008).

Untuk mengetahui peningkatan hasil belajar siswa dengan implementasi kelas virtual dengan Google Classroom maka data yang diperlukan berupa data hasil belajar yang diperoleh dari hasil belajar/nilai tes. Hasil belajar dianalisis dengan teknik analisis hasil evaluasi untuk mengetahui ketuntasan belajar dengan cara menganalisis data hasil tes dengan kriteria ketuntasan belajar, prosentase hasil belajar yang diperoleh siswa tersebut kemudian dibandingkan dengan KKM (Kriteria Ketuntasan Minimal) yang telah ditentukan. Seorang siswa disebut tuntas belajar jika telah mencapai skor 76 ke atas.

Adapun teknik analisis data yang digunakan untuk mengetahui peningkatan hasil belajar siswa pada penelitian ini yakni dengan membandingkan persentase ketuntasan belajar dalam implementasi kelas virtual dengan Google Classroom pada siklus I dan siklus II. Sedangkan persentase ketuntasan belajar dihitung dengan cara membandingkan jumlah siswa yang tuntas belajar dengan jumlah siswa secara keseluruhan (siswa maksimal) kemudian dikalikan 100\% (Purwanto, 2006).

\section{HASIL DAN PEMBAHASAN}

Hasil yang diperoleh berdasarkan pengumpulan data awal (pra-tindakan penelitian) hasil belajar kimia di SMAN 1 Serang Baru melalui dokumentasi siswa dan hasil belajar siswa terhadap mata pelajaran kimia dapat dilihat pada Tabel 1 . 
Tabel 1. Data rata-rata ulangan harian dan ketuntasan belajar siswa kelas XI-MIPA 1 tahun pelajaran 2019/2020.

\begin{tabular}{ccc}
\hline \multirow{2}{*}{ Unit kerja } & \multicolumn{2}{c}{ Ulangan harian pra-siklus } \\
\cline { 2 - 3 } & Rata-rata & \% Tuntas belajar \\
\hline SMAN 1 Serang Baru & 67,70 & $46 \%$ \\
\hline \multicolumn{2}{l}{ (Sumber: Dokumentasi Guru Kimia SMAN 1 Serang Baru) }
\end{tabular}

Proses pelaksanaan penelitian dan pengumpulan data diselenggarakan di SMAN 1 Serang Baru kelas XI MIPA 1 dengan menggunakan kelas virtual melalui Google Classroom. Sebelum melaksanakan penelitian, peneliti mempersiapkan instrumen pengumpulan data yang terdiri dari lembaran observasi aktivitas siswa, angket respon siswa, soal evaluasi siklus I dan siklus II, rencana pelaksanaan pembelajaran (RPP), dan Lembar Kerja Peserta Didik (LKPD).

Peneliti melaksanakan proses pembelajaran dengan setiap siklus terdiri dari 4 tahap yaitu: perencanaan, pelaksanaan, observasi dan refleksi. Penelitian ini dilaksanakan dalam dua siklus. Hasil belajar kimia pada materi pokok kelarutan dan hasil kali kelarutan pada siklus I dapat dilihat pada Tabel 2.

Tabel 2. Data hasil belajar kimia dan ketuntasan belajar siswa kelas XI-MIPA 1 pada siklus I.

\begin{tabular}{cc}
\hline Hasil Pengolahan Data & Hasil Belajar Kimia Pada Siklus I \\
\hline Jumlah siswa & 36 \\
Nilai rata-rata & 70 \\
Nilai Tertinggi & 97 \\
Nilai Terendah & 13 \\
Simpangan Baku & 16,06 \\
\% Ketuntasan Belajar & $70,94 \%$ \\
\hline
\end{tabular}

(Sumber: Hasil Pengolahan Data)

Hasil penelitian pada siklus I, dari total jumlah siswa sebanyak 36 orang terdapat 21 orang yang belum mencapai ketuntasan belajar secara individu yaitu siswa yang memperoleh nilai $<76$ 
sesuai dengan KKM pada mata pelajaran kimia dengan nilai 76 , sedangkan siswa yang memperoleh nilai $\geq 76$ berjumlah 15 orang dengan persentase ketuntasan belajar secara klasikal sebesar 70,94\%. Menurut Trianto (2014), kriteria ketuntasan belajar secara klasikal di sekolah dinyatakan tuntas apabila $85 \%$ siswa tuntas secara klasikal. Oleh karena itu, dapat disimpulkan bahwa ketuntasan belajar secara klasikal pada siklus I belum tercapai dan aktivitas siswa dalam pembelajaran daring masih rendah.

Peneliti melakukan refleksi terhadap pembelajaran pada siklus I, terdapat beberapa hasil temuan yang perlu diperbaiki selama proses pembelajaran. Secara umum, penjelasan hasil temuan untuk aspek-aspek yang perlu diperbaiki selama proses pembelajaran pada siklus I dapat dilihat pada Tabel 3 berikut.

Tabel 3. Hasil temuan dan revisi selama proses pembelajaran siklus I

\begin{tabular}{llll}
\hline No & Refleksi & \multicolumn{1}{c}{ Hasil Temuan } & Revisi \\
\hline 1. & Kemampuan & Kemampuan penggunaan & Siswa yang belum \\
& siswa & TIK di kalangan siswa & familiar dalam \\
& masing beragam terlihat & penggunaan kelas \\
& masih ada beberapa siswa & virtual dengan Google \\
& yang belum familiar dalam & Classroom diberi waktu \\
& penggunaan kelas virtual & untuk beradaptasi dan \\
& dengan Google Classroom & harus lebih dibimbing \\
& & dalam proses belajar \\
& & \\
& &
\end{tabular}




\begin{tabular}{|c|c|c|c|}
\hline No & Refleksi & Hasil Temuan & Revisi \\
\hline 2. & Aktivitas guru & 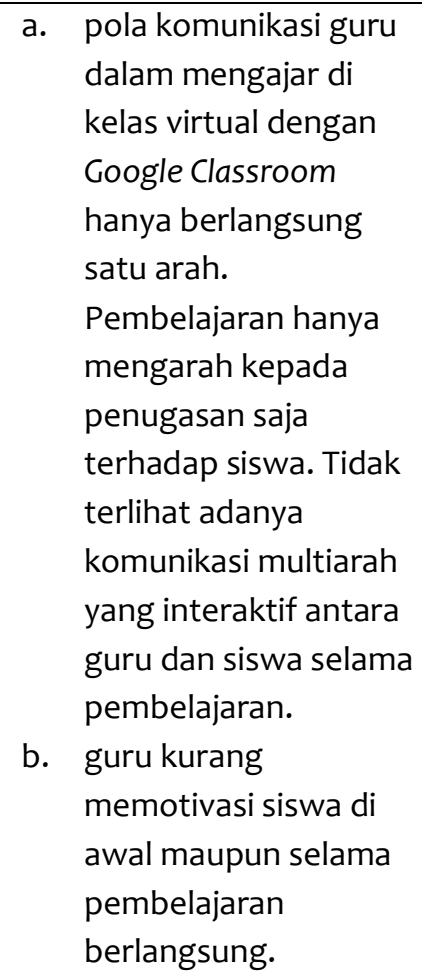 & 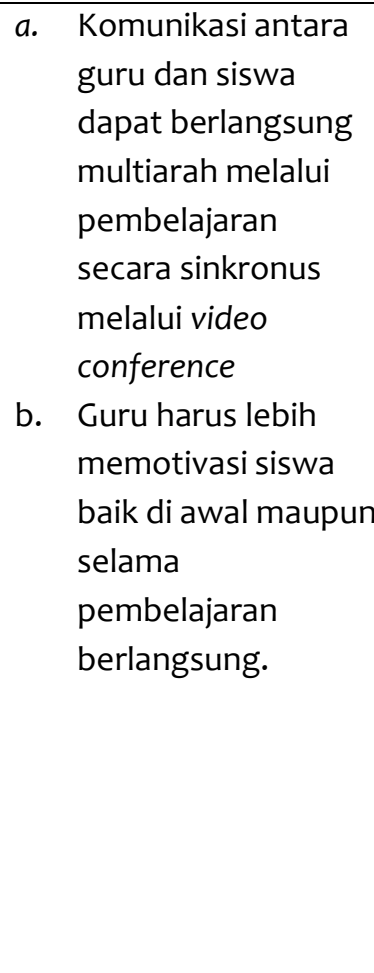 \\
\hline & $\begin{array}{l}\text { Hasil tes } \\
\text { siklus I }\end{array}$ & $\begin{array}{l}\text { Masih ada } 21 \text { orang yang } \\
\text { hasil belajarnya belum } \\
\text { mencapai skor ketuntasan } \\
\text { untuk pertemuan } \\
\text { berikutnya, dikarenakan } \\
\text { kurang menyeluruhnya } \\
\text { penjelasan guru kepada } \\
\text { siswa }\end{array}$ & $\begin{array}{l}\text { Guru harus bisa } \\
\text { menjangkau para murid } \\
\text { dalam menjelaskan } \\
\text { materi agar semua } \\
\text { siswa dapat mengerti } \\
\text { materi yang dipelajari. }\end{array}$ \\
\hline
\end{tabular}

Sumber: Hasil Temuan Selama Proses Pembelajaran pada Tindakan

Hasil temuan pada siklus I tersebut dijadikan acuan untuk melakukan revisi terhadap proses pembelajaran pada siklus II. Pada pembelajaran siklus II, guru melakukan pembelajaran dengan melakukan komunikasi yang multiarah yang interaktif antara guru dan siswa diantaranya dengan melakukan diskusi melalui fitur video conference, sehingga guru dan siswa tetap dapat melakukan tanya 
jawab secara tatap muka secara daring siswa sekaligus memberi motivasi terhadap siswa. Selain itu, komunikasi multiarah juga dilakukan melalui percakapan langsung dalam fitur yang terdapat di Google Classroom dan memberikan komentar serta umpan balik terhadap tugas-tugas yang telah dikerjakan. Kemampuan siswa dalam penggunaan Google Classroom juga semakin meningkat seiring dengan seringnya para siswa menggunakan kelas virtual ini, sehingga siswa yang tadinya kurang familiar dapat segera menyesuaikan pembelajaran dengan kelas virtual ini.

Setelah kegiatan pembelajaran pada siklus II, guru memberikan tes siklus II yang diikuti oleh 36 siswa. Data hasil belajar kimia dan ketuntasan belajar siswa pada siklus II dapat dilihat pada Tabel 4.

Tabel 4. Data hasil belajar kimia dan ketuntasan belajar siswa kelas XI-MIPA 1 pada siklus II.

\begin{tabular}{cc}
\hline Hasil Pengolahan Data & Hasil Belajar Kimia Pada Siklus II \\
\hline Jumlah siswa & 36 \\
Nilai rata-rata & 87,46 \\
Nilai Tertinggi & 100 \\
Nilai Terendah & 60 \\
Simpangan Baku & 16,17 \\
\% Ketuntasan Belajar & $88,88 \%$ \\
\hline
\end{tabular}

(Sumber: Hasil Pengolahan Data)

Hasil penelitian pada siklus II, terdapat 12 orang yang belum mencapai ketuntasan belajar secara individu yaitu siswa yang memperoleh nilai $<76$ sesuai dengan KKM pada mata pelajaran kimia, sedangkan siswa yang memperoleh nilai $\geq 76$ berjumlah 24 orang dengan persentase ketuntasan belajar secara klasikal sebesar $88,88 \%$. Sesuai dengan kriteria ketuntasan belajar secara klasikal di sekolah dinyatakan tuntas apabila $85 \%$ siswa tuntas secara klasikal, maka ketuntasan belajar siswa secara klasikal untuk mata pelajaran kimia secara keseluruhan sudah tercapai. 
Hasil penilaian aktivitas pada siklus I telah memenuhi kriteria baik sekali dengan persentase sebesar 92,31\% dan mengalami kenaikan pada siklus II menjadi 94,23\%. Hal ini menandakan bahwa aktivitas siswa tergolong aktif, dan sesuai dengan kriteria aktivitas siswa dimana 80-100\% = baik sekali. Aktivitas siswa dinilai pada saat proses pembelajaran berlangsung yang dimulai dengan kegiatan pendahuluan yaitu menanggapi apersepsi, motivasi dan tujuan pembelajaran. Pada tahap ini siswa menanggapinya dengan baik yang ditandai dengan keaktifan siswa dalam menjawab apersepsi yang diajukan melalui diskusi di Google Classroom maupun melalui video conference. Menurut Teori komunikasi pendidikan, dalam proses pembelajaran haruslah melakukan proses komunikasi (Haqien dan Rahman, 2020). Komunikasi dilakukan antara siswa dan guru atau siswa dengan siswa lainnya. Adanya kelas virtual Google Classroom yang dipadukan dengan fitur video conference yang tersedia dalam Google Classroom menunjukkan adanya komunikasi antar individu yang lebih baik karena komunikasi dapat dilakukan secara langsung. Hal ini berdampak pada peningkatan keaktifan siswa dalam pembelajaran secara online.

Jadi, dapat disimpulkan bahwa pembelajaran pada siklus II telah mencapai keberhasilan baik dari segi proses maupun dari segi hasil jika dilihat dari kriteria yang telah diteliti yaitu aktivitas siswa selama pembelajaran dan hasil belajar siswa pada mata pelajaran kimia menggunakan kelas virtual dengan Google Classroom.

Hasil penelitian yang dilakukan oleh Maskar \& Wulantina (2019) menunjukkan bahwa proses pembelajaran dengan metode blended learning melalui Google Classroom membuat proses pembelajaran menjadi menarik, efektif, menumbuhkan motivasi, menumbuhkan sikap belajar mandiri, aktif, dan kreatif (Maskar \& Wulantina, 2019). Hasil penelitian lain yang dilakukan oleh Ashoumi \& Shobirin (2019) menunjukkan bahwa Respon mahasiswa terhadap media pembelajaran yang diakses melalui kelas virtual Google Classroom, secara keseluruhan termasuk dalam kriteria "Sangat Baik" yang artinya media sangat menarik bagi mahasiswa karena membuat mahasiswa memiliki waktu lebih banyak untuk 
mempelajari materi pelajarannya dan media mudah diakses dimana saja serta kapan saja selama terhubung ke jaringan internet (Ashoumi \& Shobirin, 2019).

Hasil penelitian ini sesuai dengan kedua penelitian terdahulu, yang menunjukkan adanya peningkatan aktivitas pembelajaran dan hasil belajar melalui penggunaan kelas virtual dengan Google Classroom. Dalam pemanfaatan kelas virtual Google Classroom ini perlu juga di kombinasikan dengan fitur lain yang ada dalam Google Classroom seperti untuk melakukan video conference antara guru dan siswa sehingga komunikasi yang terjadi antara guru dan siswa dapat multiarah. Berdasarkan hasil penelitian ini, dengan menggunakan kelas virtual Google Classroom dapat meningkatkan hasil belajar kimia terutama pada materi pokok kelarutan dan hasil kali kelarutan di SMAN 1 Serang Baru. Hal ini tentunya, dapat dijadikan solusi dalam pembelajaran daring di tengah wabah pandemi Covid-19.

\section{KESIMPULAN}

Berdasarkan penelitian yang telah dilakukan, maka dapat diambil kesimpulan bahwa Capaian hasil belajar siswa setelah diterapkannya pada mata pelajaran kimia menggunakan kelas virtual dengan Google Classroom mengalami peningkatan secara klasikal tuntas dengan persentase siklus I yaitu $70,94 \%$ menjadi $88,88 \%$ pada siklus II. Selain itu, aktivitas siswa pada mata pelajaran kimia menggunakan kelas virtual dengan Google Classroom mengalami peningkatan, dengan persentase pada siklus I 92,31\% menjadi pada 94,23\%. Berdasarkan hasil yang diperoleh, dapat disimpulkan bahwa implementasi kelas virtual dengan Google Classroom dapat meningkatkan hasil belajar siswa pada mata pelajaran kimia di SMAN 1 Serang Baru.

\section{DAFTAR PUSTAKA}

Ashoumi, H, \& Shobirin, M. S. (2019, April). Peningkatan Aktifitas Belajar Mahasiswa dengan Media Pembelajaran Kelas Virtual 
Google Classroom. Prosiding Seminar Nasional Teknologi dan Sains (SNasTekS). 149-159.

Dewi, W. A. F. (2020). Dampak Covid-19 Terhadap Implementasi Pembelajaran Daring di Sekolah Dasar. Edukatif: Jurnal Ilmu Pendidikan. 2(1). 55-61.

Hammi, Zedha. (2017). Implementasi Google Classroom Pada Kelas XI IPA MAN 2 Kudus. (Skripsi) Program Studi Teknologi Pendidikan Universitas Negeri Semarang, Semarang.

Haqien, D., \& Rahman, A. A. (2020). Pemanfaatan Zoom Meeting Untuk Proses Pembelajaran Pada Masa Pandemi Covid-19. Jurnal SAP. 5 (1). 51-56.

Hikmatiar, H., Sulisworo, D., \& Wahyuni, M. E. (2020). Pemanfaatan Learning Management System Berbasis Google Classroom dalam Pembelajaran. Jurnal Pendidikan Fisika. 8 (1). 78-86.

Maskar, S. \& Wulantina, E. (2019). Persepsi Peserta Didik Terhadap Metode Blended Learning dengan Google Classroom. Jurnal Inovasi Matematika. 1(2). 110-121.

Mendikbud Terbitkan SE tentang Pelaksanaan Pendidikan dalam Masa Darurat 2020. (https://www.kemdikbud.go.id/main/blog/2020/03/mendikb ud-terbitkan-se-tentang-pelaksanaan-pendidikan-dalammasa-darurat-covid19, diakses 15 Juli 2020)

Purwanto, Ngalim. (2006). Prinsip-Prinsip dan Teknik Evaluasi Pengajaran. Bandung: Remaja Rosdakarya.

Redhana, I. W. (2019). Mengembangkan Keterampilan Abad Ke-21 Dalam Pembelajaran Kimia. Jurnal Inovasi Pendidikan Kimia. $13(1), 2239-2253$. 
Bintarawati, D. \& Citriadin, Y. (2020)

Doi: 10.20414/spin.v2i2.2573

Sugiyono. (2008). Metodologi Penelitian Kuantitatif dan Kualitatif. Bandung: Alfabeta.

Suhada, I., Kurniati, T., Pranadi, R. A., \& Listiawati, M. (2020). Pembelajaran Daring Berbasis Google Classroom Mahasiswa Pendidikan Biologi Pada Masa Wabah Covid-19. Digital Library UIN Sunan Gunung Djati. 1-10.

Suhardjono. (2009). Penelitian Tindakan Kelas. Jakarta: Bumi Aksara. Suharsimi. A. (2009). Penelitian Tindakan Kelas. Jakarta: Bumi Aksara Trianto. (2014). Model Pembelajaran Terpadu. Jakarta: Bumi Aksara. 